\title{
THE SHORT HISTORY OF THE MINISTRY OF TECHNOLOGY
}

The British Ministry of Technology was created in October 1964, after the General Election in that year. The plan for such a Ministry was itself an important part of the discussions within the Labour Party in the months preceding the election. The chief argument in its favour was that the government of a modern industrial nation requires a concentration of power in an organization capable of initiating change. To begin with, crities of the then arrangements for sponsoring and fostering industrial development and research were able to point to the diversity of the interests concerned-the Department of Education and Science, the Ministry of Aviation, the Board of Trade, the Ministry of Power, not to mention a number of independent public bodies such as the United Kingdom Atomic Energy Authority. The first objective, then, was to unite as many as possible of these entities in one organization.

In the event, the Ministry of Technology created in October 1964 was less grand. In the arrangements for organizing civilian science and technology, the Department of Education and Science has retained responsibility for the research councils whose chief function is to support scientific research in universities and elsewhere, but which also carry out some work of their own. (Thus the Science Research Council is directly responsible for running the Radio and Space Research Station at Slough.) The Ministry of Power remains formally responsible for fostering scientific research in power generation, while, for most of the past twenty months, the Ministry of Aviation has retained responsibility for a number of research establishments, some of which are directly concerned with defence and others with more civilian developments, and has thus been an ironic reminder that some of the earliest plans for the Ministry of 'Technology assumed that it would be constructed around the Ministry of Aviation.

To begin with, the Ministry of Technology was made responsible for ten research stations transferred from the old Department of Scientific and Industrial Research (Table 1), together with the United Kingdom Atomic Energy Authority. At the same time the Ministry of Technology was made responsible for the co-operative research associations, which were again transferred from the Department of Scientific and Industrial Research and which are financed partly by government grant and partly by contributions from the industries concerned. The Ministry of Technology was also, from its creation, given responsibility for the National Research and Development Corporation, whose job it is to invest public money in the development of new processes and devices (the most profitable of which has been the Bailey bridge and the best known the Hovereraft). The Ministry of Technology became formally responsible for these various institutions within a few months of the creation of the Ministry; the transfer of power was complete by the beginning of April 1965.

The Atomic Energy Authority consumes roughly ten times as much money as the laboratories and engages not merely in research and development but also in the production of nuclear materials and the processing of spent uranium fuel. Since the inception of the Ministry of Technology it has been assumed that the Atomic Energy Authority will somehow diversify its activities, taking on pieces of research and development on behalf of industry. As yet, there is little to show how successful this policy has been.

With its creation, the Ministry also assumed responsibility for the industrial research associations, now fortyeight in number and requiring annual expenditure

\begin{tabular}{lcc}
\multicolumn{1}{c}{ Table 1 } & \multicolumn{2}{c}{$1966-67$} \\
& Cost & No. of \\
& $(£)$ & people \\
Building Research Station & 936,000 & 693 \\
Fire Research Station & 187,000 & 149 \\
Forest Products Research Laboratory & 239,000 & 177 \\
Hydraulics Research Station & 257,000 & 235 \\
Laboratory of Grovernment Chemist & 570,000 & 395 \\
National Engineering Laboratory & 940,000 & 795 \\
National Physical Laboratory & $2,216,000$ & 1,661 \\
Torry Research Station & 229,000 & 198 \\
Warren Spring Laboratory & 505,000 & 398 \\
Water Pollution Research Laboratory & 228,000 & 171 \\
& $-307,000$ & 4,872
\end{tabular}

estimated to amount to $£ 3,570,000$ in 1966 . In addition, the Ministry is reckoning to spend $£ 750,000$ on research and development contracts, a roughly similar amount on a scheme to purchase from industry advanced machine tools and other devices where it is thought that development is held up for lack of customers, $£ 700,000$ on advice for industry, $£ 290,000$ in launching the National Computing Centre, and $£ 400,000$ on support for the British Standards Institution.

As yet, it is not clear how much of the work of the Ministry of Aviation will be transferred to the Ministry of Technology in the autumn of this year. One of the first tasks to be tackled by the new Permanent Secretary to the Ministry of Technology, Mr. Richard Clarke, will be to work out a rational division of the Ministry of Aviation. Some of the defence research establishments will no doubt be transferred to the Ministry of Defence, but it seems clear that the Ministry of Technology will also grow in the process. Certainly its capacity for research will be strengthened in solid-state physics, electronics, and aerodynamics.

In its responsibility to Parliament for the National Research and Development Corporation, the Ministry of Technology has been able to sponsor an increased budget. In the year ahead it plans to invest a further $£ 5$ million of public money in the work of the National Research and Development Corporation. At the same time it has been agreed that the Corporation should write off some $£ 2.5$ million of interest accumulated since 1947 on capital borrowings from the Treasury and unlikely to be paid in the near future. To the extent that this step represents an admission that an organization instructed to take chances on research and development projects cannot always make a profit, it is likely that the Corporation will now feel more free than it has done to engage in risky enterprises.

Apart from its direct responsibility for institutions like these, the Ministry of Technology has an avuncular relationship to British industry as a whole. Much of the energy of its officials has gone into detailed enquiries into the state-technical and economic-of particular sectors of industry. There have, for example, been enquiries into machine tools and optics. The Ministry is not merely concerned to find out; it also hopes that the process of enquiry will stimulate industries to seek remedies for problems which become apparent.

In recent months the Ministry has been particularly active internationally. For one thing, it is trying to introduce British manufacturers to standards (of measurement and of specification) in use elsewhere in the world, in the hope of making exports easier to come by. It is also spending an increasing amount of its energy in dealing with the difficulties which beset British manufacturers wishing to sell things abroad, sometimes using its influence to persuade another department of the British Govern. ment to remove some fortuitous obstacle to trade. 